\title{
Paralinguistic means of speech
}

\author{
Akhmedova Rano Ashurovna ${ }^{1}$ \\ ${ }^{1}$ Bukhara State University, Uzbekistan \\ Email:akhmedova_r@umail.uz
}

\begin{abstract}
In this article, the author states about the paralinguistic means and their types. The ideas are proved with the examples taken by fictional works.
\end{abstract}

Keywords: Paralinguistic means of speech, phonological paralyzing tools, kinetic, paralinguistic tools.

\section{INTRODUCTION}

Gestures, facial expressions, body movements, and different types of voice are additional tools involved in communication. They carry out tasks such as transmitting certain information, filling in content and clarifying information. In live speech, a person uses non-linguistic tools, depending on the circumstances and conditions, to convey information briefly and concisely, to increase the emotional impact of the idea. When communicating with the Uzbeks, the meaning is also expressed through the use of hands, head, shoulders, body, facial movements, and loud, lingering, interrupted speech while conveying information to the listener.

For example, by hand motion:

a) Neglect:

- I know everything! But the chairman should be sheltered. He paused for a moment and patted my grandfather's shoulder, "Maybe he really knows what to do." He is young and clever boy.

Grandpa shrugged his neck and shaking his hand said:

He is a clever boy.... He said he has no any paper...

- paper? said an oldman, smiling [6,61].

b) Disagreement:

- Bashirjon entered the maternity hospital on the way. He gave his belongings to the sanatorium, and he went back to the back of the building and looked out the second-floor window. A short time later Zevarkhan appeared in a white robe. Their faces were cheeky and their eyes were swollen. Bashirjon shouted, "How are you?" His wife frowned and shook her hand, "Hey, go!" And turned away [ 1, 67].

c) Not speaking:

"You know when you're done," said Tesha, meaningfully. Then he shook his nervous hand to see that his mood was ruined. - All right, let's not start again. You will not wait any longer $[4,91]$.

d) Neglect, distrust:

"You know, Shamsi aka," Bashirjon said encouragingly, "it's blood pressure." Thank you. Dad also had blood pressure.

"Let me go," said Shamsi Turaevich, shaking his hand. "Your father was a poppy of thanksgiving. [1, 45].

\section{Shoulder movement:}

a) Unaware:

Bashar started to ask Olimjon with red eyes in his sleep.

- Tell the truth! When did you get water?

"When the moon raises" - Olimjon stared at me and then Bashar. God damn it is true that I brought water to my sister in law.

"What time is it?"

- How do I know? - Olimjon pulled his nose and shrugged his shoulders [6, 291].

B) Modesty:

Umar turned to doctor and asked in a solemn tone:

"Will you speak?" 
The doctor shrugged his shoulders.

"What am I saying ..." He glanced at the hall and added in a low voice:

- Let the war end quickly. May Ochilvoy come safe! [6,198].

C) Discrimination, fear:

Bashirjon's heart was full and his tongue stopped speaking.

"I told you not to worry; the boy's heartbeat is rattling ..."

- What about the other places? Bashirjon asked, stroking his shoulder strangely. - Will he born healthy? [1, 41].

\section{Through lips:}

A) Ignore:

The house was filled with concubines. The death of the poor captives caused the deaths of those who were in the bosom of the poor. Gulchehrabibi has arrived. He is now a little lonely. The old woman looked at the corpse with a terrible cold. His lip turned, sighed and turned away. Although the girls wept aloud, she gave a nod [3, 250].

b) Unpleasantness:

When I saw Zuhra kelin and I remembered those words. It is really a pale color, with scratchy eyes.

"Come in," he said, his thin lips curled up [6, 65].

c) Wonderment:

- I went to the head of the boiler. I climbed the porch. I wanted to sleep. I didn't sleep well tonight. Then I went home again. The ladies were sitting in four directions, everyone was busy with the "nine or nine" touch. One smiles with joy and another turns his lips. [6, 65].

Clearly, linguistic analysis is incomplete if it is explored by ignoring nonverbal means of expression such as this. In some cases, without nonverbal means, the idea becomes naked, logically incomprehensible, and psychologically wrong.

Paralinguistic tools not only supplement the information expressed through linguistic forms, but also provide information about the speaker, his or her level of education, social and age characteristics, gender, and traits. Although paralyzing tools are not part of language and speech units, communication is one of the most important elements of communication.

In the dialogue, the speakers interact with each other, not only by words, but also by means of facial expressions, gestures, timbre and tone. An intimate conversation can also be interesting, meaningful and persuasive.

Paralyzing tools are grouped by their communicative and somatic nature as follows:

1. Phonological paralyzing tools. The positive or negative attitude of the speaker is reflected in the tone of voice and in the tone of voice when expressing it. Decrease or increase in volume; with or without pause; speaking in a thick, thin voice; tone features in speech process are additional factors that provide specific information in communication interventions.

"So, Jannat, are you at home?" [2, 33] - As the interviewee is approaching from a short distance, the voices do not continue.

At the same time, it was heard from far away, "Jannnaaaat," [2,153) - in addition to the linguistic means ("from far away"), the meaning of the word is paradise.

- Sleep, my baby, I'm tired.

"Mommy, tell me a tale."

- Teeeeell [7, 13] - supplication, strain.

"Hello, Grandma," she says.

- Waalaykum Assalam, be mullah, says Erman grandmother [7, 51] - affection, kindness.

- Why did you come? She said with anger. - What do you want? [7,143] - Anger and hatred.

After that Khoja's mother bent down, picked up her bag, and headed for the door. Egamberdi aka moved away as if he despised. Then Khoja, who had been silent for a long time, was trying to get her mother.

"Moooom!" [7, 144] - supplication.

2. Kinetic Paralinguistic Tools. Such nonverbal means include the expression of various information by means of the actions of certain organs of the person in communication interventions related to speech communication. Examples include gestures, facial expressions, and body movements such as: 
Khamolkhanov waited for the answer and the phone rang as if it was a sign.

"When Qobil grandfather met him, sure, he bent down hard and then laughed,"

"Amin laughed.

Kinetic nonverbal means are subdivided into:

1) Sign.

2) Mimic.

1) Signal nonverbal means include the movements of the head, fingers (shoulders), shoulders, body, which is used to express a particular meaning:

- Bashirjon Zaynievich! - Ilhomjon was standing at the door.

- What's the matter?

The deputy pressed his throat and smiled right.

- Drinking? [1, 70].

Bashirjon got intoxicated and began to pour some pleasure into his heart. To Ilhomjon with this pleasure:

"Driving faster, you're late!" She said.

"Yes ... the wedding has just begun!" He said. "The red is the same as it is!" He said, pointing his thumb $[1,47]$.

The text represents the mark ("excellent") with the finger.

2) Mimic nonverbal means the transmission of certain information to the target by the person's face, eyes, eyebrows, tongue, teeth, and nose. Mimicry is associated with the human emotion and is considered "ancient" among nonverbal means, which naturally form and develop in the social environment. Mimic nonverbal means are one of the most commonly used methods of expression, because the face of a person has different meanings, changes in communication, monologic speech, inner monologue, thinking and silence. Sixty percent of nonverbal tools used in a ten-minute dialogue are used as mimic nonverbal means, and mimic nonverbal devices are also used when using kinetic paralinguistic or phonological paralysis. Because a human being is a living organism, its reaction to any information is manifested by facial movement.

The eye is an organ that is actively involved in the communication and interference of the person and plays an important role in conveying emotion. When expressing a particular meaning in the eye, two features can be observed:

a) Direct eye movement;

c) Indirect movement of the eye.

Different meanings can be conveyed through direct closure of the eye, contraction, large opening. These actions refer to a particular event, character or action, and this nonverbal means is pure contextual and situational:

He walked over to the wood, as if he had remembered it. - Hurry up, Muzaffar! Let's see what happens to your wedding?

- He winked, "I'm going to show you something now," and began to lower the blankets on the bench [6, 111].

I waited for Abduvali to come behind Urikzor. I was anxious. The cigar is really tasty. My dad smokes a pack every day! Abduvali beat his two pockets.

- Come on! I picked up a match, said the wink, as if to say, "We are five" [6,383].

Indirect motion of the eye, also looking at the eye, can also be expressed in a particular meaning. In communication, we can "see" (eye), "irritate" ("read"), "surprise" ("shine"), "pay attention" ("look"), "look" in meaning.

Sultanali pulled out the paper and looked at them again. All three were seriously employed and did not raise paper. The Sultanali went out. Shortly afterwards, Shahodat looked at Anwar slowly. Anwar was very attached to his work. Shahodat and mufti looked at each other and shook head as if "it was not good" [5, 175].

The boy shook his head from the window. Olimjon asked loudly:

"Where's your father?" 
The boy waved his palm, saying, "Don't talk!", Holding his mouth with his hands, twinkling his eyes and saying "tssss," and went back [1,295].

\section{CONCLUSION}

Both the speaker and the listener combine their speech and the listening process with paralegal means - various actions and gestures. Even when reading a book, the listener - that is, the reader sometimes squeezes his eyebrows, smiles — and sometimes hears signs of surprise on his face. These are all paralyzing tools.

\section{REFERENCES}

1. Aminov Nemat. Qahqaha. Stories. - Tashkent: Literature and Art Publishing house by Gafur Gulom, 1987.-352p.

2. Ahmad Said.Ufq. - Tashkent: Literature and Art Publishing house by Gafur Gulom, 1976. $688 \mathrm{p}$.

3. Oybek.Navai. - Tashkent: Uqituvchi, 1985. - 440p.

4. Qahhorov Abdulla. Works. Five Volumes. First volume.Sarob. - Tashkent: Literature and Art Publishing house by Gafur Gulom, 1987. - 336 p.

5. Qodiriy Abdulla. Mehrobdan chayon. - Tashkent: Uqituvchi, 1987.-241p.

6. Hoshimov Utkir.Ikki eshik orasi. - Tashkent: Literature and Art Publishing house by Gafur Gulom, 1986. - 560p.

7. Hoshimov Utkir.Nurli dunyo. - Tashkent: Shark, 1998. - 684p. 